\title{
What Happened to The Workforce?
}

\section{Terry Jaqua}

To Link this Article: http://dx.doi.org/10.6007/IJARBSS/v12-i1/12002

DOI:10.6007/IJARBSS/v12-i1/12002

Received: 12 November 2021, Revised: 16 December 2021, Accepted: 28 December 2021

Published Online: 17 January 2022

\section{In-Text Citation: (Terry Jaqua, 2022)}

To Cite this Article: Terry Jaqua. (2022). What Happened to The Workforce? International Journal of Academic Research in Business and Social Sciences, 12(1), 919-923.

\section{Copyright: (C) 2022 The Author(s)}

Published by Human Resource Management Academic Research Society (www.hrmars.com)

This article is published under the Creative Commons Attribution (CC BY 4.0) license. Anyone may reproduce, distribute, translate and create derivative works of this article (for both commercial and non0-commercial purposes), subject to full attribution to the original publication and authors. The full terms of this license may be seen at: $\underline{\text { http://creativecommons.org/licences/by/4.0/legalcode }}$

\section{Vol. 12, No. 1, 2022, Pg. $919-923$}

Full Terms \& Conditions of access and use can be found at http://hrmars.com/index.php/pages/detail/publication-ethics 


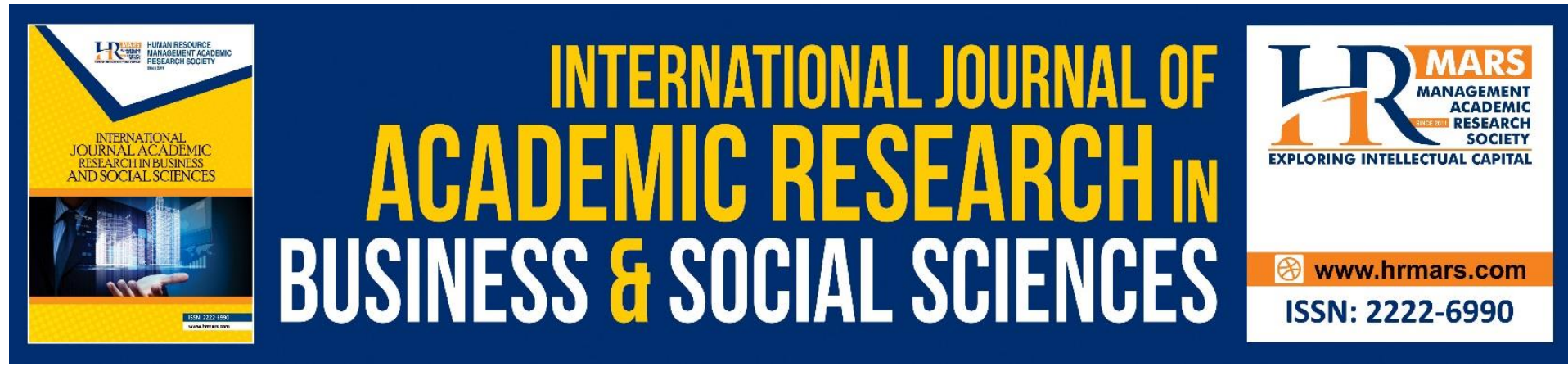

\title{
What Happened to The Workforce?
}

\author{
Terry Jaqua, Ph.D. \\ MBA - San Antonio Regional Hospital, 999 San Bernardino Rd. Upland, CA 91786 US.
}

\section{Abstract}

The impact of the COVID-19 pandemic has stretched far beyond global health. Still, the economy has also received a seismic hit, where supply chain and labor shortages have become a problem for businesses globally. Interestingly, numerous people voluntarily quit their jobs the exact same time the economy reopens, and the demand for workers is rising, which is a noticeable feature in the labor market. According to economists, labor shortages are caused by changing demographics such as aging and retiring, border controls and immigration limits, demands for better wages, and flexible working agreements. Retail trade, hospitality, restaurants, healthcare, and the educational sectors are most affected by workers quitting their jobs. In addition, the economy of the United States is opening up in a historical recovery that is being characterized by the lowest rate of labor force involvement in more than four decades and a record tally of unfilled positions. This fact has left numerous concerned parties wondering where all the workers have gone.

\section{Objectives}

- The objective of this research is to outline the scarcity of workers in the U.S. labor market, which has undoubtedly reshaped of the U.S. labor force.

- Provide theoretical answers to where the work force has gone, and alternatively provide solutions facing businesses today on how to deal with the shortages.

\section{Current Labor Market State of Affairs}

In the United States, the labor force participation rate has lingered near its lowest since 1970 for almost a year, and it will not be moving anytime soon, even by adding close to a million jobs. This is the most significant drop in the participation rate has encountered despite remaining so even with solid economic growth and the sturdiest wage gains in years (Cambon et al., 2021). Moreover, labor participation has cut across all demographic groups and fields. Specific drops have been encountered among women in the workforce, workers lacking college degrees and those in low-income sectors such as restaurants. It was the hope that with the unemployment benefits expiring, schools were reopening, and the delta variant fading, labor force participation would improve this fall of 2021 but the evidence point to an increase in labor shortages. This also supports the notion that labor force participation has been falling unchangingly. Additionally, businesses and policymakers in the United States will have to combat the lasting shifts that make some jobs unnecessary.

There is a multitude of reasons responsible for the labor shortages. Likely, workers who have been sidelined due to layoffs, disability, lack of daycares, the closure of schools and 
businesses experiencing skill lapse, which will be a challenge for them in their attempts to enter the job market. This is likely to lower the capacity of the United States labor force even further. In June, the tally for Americans who have been unemployed for a year hit 2.9 million, which is the equivalent of $29 \%$ of the entire jobless population (Spiggle, 2021). Additionally, the pandemic crisis caused workers who were rendered jobless to rethink and reconsider their career choices. Research conducted in February by Pew Research found that consequent to the rethinking of career choices, approximately two-thirds of the unemployed population in the United States critically considered changing their occupations or areas of expertise during the pandemic. Additional research indicates that one out of five workers changed their occupations entirely. The phenomenon of employees leaving their profession is an experience that I have personally felt in the healthcare sector. Employees in the healthcare sector are experiencing burnout, and some have left the healthcare sector to explore different occupations and careers due to the pandemic.

In response to the COVID-19 pandemic, the government, following the directives issued by the department of health, executed several measures to curb the spread including the spread of the new Omicron variant. These measures have impacted the economy from different angles, and some have caused labor shortages (Rockeman, 2021). Before the pandemic, the labor pool was vast because immigrants and worker visas were allowed in the labor force. Still, the pandemic resulted in closures of these borders and delays or restrictions to the work visa programs, and in turn, the availability of the immigrant labor pool was reduced. Nevertheless, the immigrant labor force is an essential pool of workers, which helps with the low fertility rate the United States is experiencing today. The slow US population growth is partly due to the low fertility rate of 1.7 for 2021, an increase from 2020 that was 1.6. This number is well below the replacement level fertility rate of 2.1 children per woman necessary to keep the population steady (USA Today, 2020).

Additionally, the pandemic caused the government to chip in for the citizens who lost their employment and wages (Cambon et al., 2021). Consequently, trillions of dollars were directed at federal relief programs, and as a result, numerous workers are not yearning to return to their previous modestly paid, demanding jobs. The governments' response made it possible for Americans to create and increase their savings. Still, according to economists, workers are failing to take these jobs is not entirely based on these savings. Instead, they maintain that the support provides a platform for workers to be picky about most positions.

Childcare issues are also a factor along with health issues. Part of the economy reopening involves the reopening of schools. Still, this process of reopening has slowed considerably, which has caused parents to have to battle quarantines or temporary resumption to remote learning. Additionally, the daycare industry is facing a staffing crisis, and as a result, parents with young children face challenges finding daycares that have also become more expensive (Casselman, 2021). Consequently, this wave in the economy has motivated parents to stay home with their children rather than return to work. This issue has predominantly affected women in the workforce, which most likely will further widen the wage disparities among men and women. Childcare is tied to a decline we have experienced in the participation of women in the workforce, which stood at $56.2 \%$ in June compared to the century's high-water mark of $60.3 \%$. This is chiefly due to women contributing as primary caregivers and the COVID-19 pandemic causing a fundamental shift between work and childcare, which may be permanent.

The onsite workforce has become synonymous with being unsafe, so to many, due to the pandemic, workers are turning down jobs as they demand better pay, flexible hours, and 
better benefits. August witnessed a record of 4.3 million people calling it quits on their careers, where some left mid-shift for a better-paying position within the same vicinity (Rockeman, 2021). The pandemic served as a revelation about how critical working conditions are to workers. They continue to prefer working remotely if at all they choose to work. However, if the job demands in-person presence, then it has to be worth the risk of contracting COVID-19.

Additionally, baby boomers are retiring at a very high rate, and some are leaving the workforce earlier than planned. Boomer workers reached retirement a decade ago, and their leaving is voluntary and involuntary (Cambon et al., 2021). Those who left voluntarily are taking advantage of their fattened portfolios by the bull market, while there are those who left because job losses forced them out as a result of the pandemic and their prospect of securing another position is slim. This has been detrimental to the employers because they cannot secure experienced labor which these boomer workers possessed from numerous years in the labor market. Those entering the workforce fail to exhibit the willingness to put in the work or make sacrifices, which is one of the reasons many economist and scholars refer to 2021 as The Great Resignation or Reset.

Lastly, the increase in governmental social assistant programs competing against the private sector has also caused citizens to stop looking for jobs. Unemployment benefits continues to grow, food stamps, social welfare programs and eviction moratoriums have caused many workers to be dependent on government support and now have adopted a position to leave the job market entirely. Most recently the federal government unemployment rate numbers are being reported to have hit a low 3.9 percent in January 2022 according to the U.S. Department of Labor - BLS (2022). This number is misleading because it only represents the amount of people who are actively looking for work, it does not account for the 4.3 million workers who have left the workforce entirely, which explains why so many businesses in the U.S. are still short of workers.

\section{Alternative Solutions to the Labor Shortages}

In response to labor shortages, employers can embrace and utilize different measures. One approach is automation in businesses and industries. Automation is not a new approach; it has been in existence for the last 10-15 years and what the pandemic did was accelerate the adoption process. Automation involves incorporating technology with the duties previously performed by workers who are now unavailable (Endo et al., 2021). According to Rockman (2021), the confirmation of automation is evident in hospitals where nurses can monitor the vitals of the patients remotely and robotics in surgeries and robotic sterilization practices such as UV lights; similar automation is evident in the restaurant industry with barcodes in menus. Likewise, fast food chains are adding robotics to help with the assembly and food production.

Another response to the labor shortages is in the method of raising workers' wages. Raising wages is a valid point even though it defeats the purpose of the practicality of throwing money on problems that are easier in practice. To understand why raising wages is a viable approach, examine the outcome of taking the risk of failing to raise wages. First, it leads to poor customer service, which is reflected in reduced sales, and then it becomes clear that either way, the fight to get executive support is an uphill battle.

Employers concerned with employee wellness can also provide student loan repayment options to increase worker retention. Approximately one-third of students have to use student loans to get through college, and on average, the student loan debt hit a record 
high of $\$ 38,792$ in 2020 . The Federal Reserve Bank of New York indicates that the collective student loan is approximately $\$ 1.6$ trillion. Perhaps the U.S. Congress to pass laws that offer employers tax write-off incentives for student loan repayment, which would fix the student loan debt problem. It is important to note that in March 2021, Congress passed the American Rescue Plan, it includes the provision that student loan forgiveness provided between January 1, 2021, and December 31, 2025, will not be taxable to the recipient.

Yet another different approach is that of requesting the existing workforce to work overtime. Data from the Department of Labor indicates that workers in the manufacturing sector worked an average of 4.2 overtime hours weekly compared to 2.8 hours in April 2020. Overtime hours reduce several costs and the need to hire new workers; however, despite workers enjoying the extra money, some exhibit feelings of exhaustion and overworking.

In conclusion, the scarcity in the labor force is becoming a permanent part of the U.S. Labor market landscape, which undoubtedly has triggered a reshaping of the U.S. labor market, causing higher wages, changes in benefits, increase of remote workers, and an increase in business automation. A staggering 4.3 million workers have left the workforce initiating what many have christened as The Great Reset or Resignation. The contextual factors presented here characterize a permanent shift in the U.S. labor force. This phenomenon has profoundly changed the labor market landscape. This research proposes a theoretical answer to the question of what happened to the U.S. worker force and provides solutions to the ongoing problems facing worker shortages today.

\section{References}

Cambon, J. M., Lauren Weber, and Sarah Chaney. (2021). 4.3 Million Workers Are Missing. Where Did They Go? Wall Street Journal. https://www.wsj.com/articles/laborshortage-missing-workers-jobs-pay-raises-economy-11634224519

Casselman, B. (2021). The Economic Rebound Is Still Waiting for Workers. The New York Times. https://www.nytimes.com/2021/10/19/business/economy/us-economy.html

Peter, K. A., Halfens, R. J. G., Hahn, S., \& Schols, J. M. G. A. (2021). A cross-sectional study is associated with work-private life conflict and leadership qualities among line managers of health professionals in Swiss acute and rehabilitation hospitals. BMC Health Services Research, 21(1). https://doi.org/10.1186/s12913-021-06092-1

Rockeman, O. (2021). Bloomberg - The Mystery of the Missing Workers, Explained. Www.bloomberg.com. https://www.bloomberg.com/news/features/2021-0805/why-is-u-s-labor-force-shrinking-retirement-boom-opioid-crisis-child-care

Spiggle, T. (2021). What Does A Worker Want? What The Labor Shortage Really Tells Us. Forbes. https://www.forbes.com/sites/tomspiggle/2021/07/08/what-does-a-workerwant-what-the-labor-shortage-really-tells-us/?sh=2589187d539d

USA Today. (2020). Another economic blow: A slowdown in US population growth worsened by COVID-19. USA

TODAY. https://www.usatoday.com/story/money/2020/12/10/economy-covid-19worsens-slowdown-population-growth-economy/3865429001/

U.S. Department of Labor. (2022). The Employment Situation - News Release. U.S. Bureau of Labor Statistics. https://www.bls.gov/news.release/pdf/empsit.pdf 